\title{
Perancangan Sistem Penunjang Keputusan untuk Menentukan Jabatan Pengurus Organisasi Menggunakan Kombinasi Algoritma Simple Multi Attribute Rating Technique (SMART) dan Forward
}

Chaining

\author{
Mardhiya Hayaty*, Restu Fajri Irawan \\ Program Studi Informatika \\ Universitas AMIKOM Yogyakarta \\ Yogyakarta \\ *mardhiya_hayati@amikom.ac.id
}

\begin{abstract}
Abstrak-Kebutuhan informasi pada era sekarang sangat tinggi, sehingga diperlukan pemprosesan data yang cepat, akurat, dan tepat. Informasi yang dihasilkan harus berkualitas sehingga dapat digunakan untuk pengambilan keputusan. Algoritma Simple Multi Attribute Rating Technique (SMART) adalah algoritma yang digunakan untuk pengambilan keputusan dengan menggunakan multikriteria, setiap kriteria memiliki nilai dan diberikan kepada setiap alternatif sehingga menghasilkan jumlah peringkat pembobotan untuk mendapatkan alternatif terbaik. Penggunaan algoritma SMART tidak dapat menentukan hasil secara spesifik seperti rekomendasi posisi jabatan sebuah organisasi, tetapi hanya berdasarkan peringkat tertinggi sebagai dasar seleksi calon pengurus, untuk mengatasi hal tersebut penelitian dikombinasikan dengan algoritma Forward Chaining. Proses algoritma Forward Chaining mensinkronkan fakta-fakta yang ada dengan rule yang telah ditetapkan dengan cara penelusuran secara runtut maju melalui penalaran logika IF-THEN, sehingga implementasi algoritma Forward Chaining dapat merekomendasikan posisi jabatan calon pengurus pada sebuah organisasi. Penelitian ini telah menghasilkan 25 orang kandidat pengurus organisasi dengan nilai terbaik dan sekaligus merekomendasikan posisi jabatan sekretaris sebanyak 3 orang, 2 orang bendahara, 4 orang jabatan aspirasi, bagian humas 4 orang, LITBANG berjumlah 5 orang, keorganisasian sebanyak 5 orang, 1 orang jabatan LITBANG atau jabatan aspirasi serta jabatan bendahara atau sekretaris sebanyak 1 orang
\end{abstract}

Kata kunci: Simple Multi Attribute Rating Technique, SMART, Forward Chaining, Sistem Penunjang Keputusan.

\section{Pendahuluan}

Pada era sekarang, kebutuhan informasi sangat tinggi sehingga pemrosesan data dituntut cepat dan informasi yang diperoleh harus akurat, informasi yang diperoleh dipergunakan sebagai pendukung pengambilan keputusan. Pengambilan keputusan sering terjadi kesalahan apabila tidak didukung informasi yang akurat[1]

Simple Multy Attribute Rating Technique (SMART), SMART adalah suatu metode pendukung keputusan menggunakan multi kriteria, setiap alternatif memiliki beberapa jumlah kriteria dan setiap kriteria memiliki nilai atau bobot peringkat, pembobotan digunakan pada setiap alternatif untuk memperoleh alternatif terbaik[2].

Penelitian sebelumnya, metode SMART telah digunakan untuk perhitungan kuantitatif dalam model pengambilan keputusan[3],[4]. Penelitian ini menghasilkan seleksi pemain-pemain terbaik pada sebuah turnamen tetapi tidak dapat menentukan posisi pemain[4]. Penelitian yang telah dilakukan penggunaan metode SMART hanya dapat menentukan pendukung keputusan secara umum (hanya kandidat jumlah anggota) dan tidak spesifik seperti menentukan posisi, jabatan dan indikator-indikator spesifik lainnya. Oleh karena itu metode SMART akan dikombinasikan dengan metode Forward Chaining.

Forward Chaining merupakan suatu metode pencarian yang dimulai dari informasi-informasi yang ada dengan pengabungan rule, metode ini juga dinamakan dengan metode pelacakan maju karena proses pencarian informasiinformasi dilakukan di awal kemudian mendapatkan penyelesaiannya (penalaran dari masalah kemudian solusi) [5]. Penelitian sebelumnya dari metode ini digunakan sebagai metode yang membantu pengambil keputusan dari hasil perhitungan data bahan untuk laboratorium, metode pada penelitian ini memiliki kelemahan yaitu datadata yang dimasukkan kurang probalistik sehingga butuh dikombinasikan dengan metode yang lain untuk menutup kelemahannya, akan tetapi untuk pemilihan prioritasnya mana supplier yang penting metode ini sangat berjalan dengan baik [6]. 


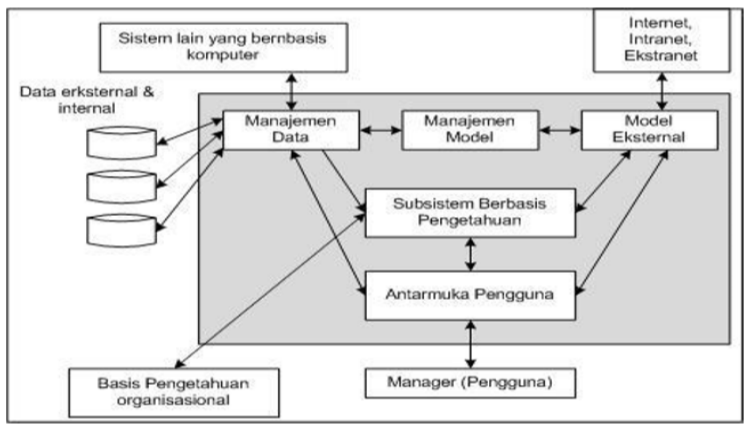

Gambar 1. Arsitektur decisions support system

Penelitian lain dengan tingkat akurasi yang didapatkan sebesar $82 \%$ sudah akurat, dan metode Forward Chaining dipilih karena sudah sering dipakai diberbagai penelitian[7]. Kemudian penelitian yang lainnya, metode Forward Chaining ini digunakan untuk menghitung dan memberikan hasil kesimpulan dari input yang diberikan, dan kesimpulan yang dihasilkan kemudian akan diproses oleh alat dan dalam alat tersebut, metode ini bisa berjalan dengan sangat baik dalam memberikan kesimpulan dan pengendali[8]. Penelitian yang telah dilakukan di mana metode ini belum bisa memasukkan data-data probalistik yang membuat datanya tidak dapat secara fleksibel berubah sehingga metode ini harus digabungkan dengan metode yang lainnya.

Metode untuk menentukan calon kandidat pada kepengurusan sebuah organisasi selama ini masih bersifat manual, tidak adanya parameter yang jelas untuk mengukur kompetensi seseorang sehingga unsur subjektivitas masih sangat besar, selain itu penggunaan metode yang ada belum mampu menjawab kebutuhan akan pentingnya penentuan orang yang tepat untuk dipekerjakan di posisi jabatan yang tepat (the right man on the right place), rotasi jabatan kepengurusan organisasi setiap periode tertentu menjadikan struktur organisasi bergerak dinamis, sehingga perlu dirancang sebuah sistem pendukung keputusan untuk mengakomodasi kebutuhan tersebut.

Berdasarkan permasalahan tersebut, penelitian ini berfokus pada perancangan sistem penunjang keputusan untuk kepengurusan organisasi dengan menggunakan kombinasi metode SMART dan Forward Chaining agar informasi yang dihasilkan dapat mendukung sebuah keputusan yang tepat, proses diawali dengan seleksi rating menggunakan algoritma SMART, kemudian hasil dari rating seleksi menjadi parameter input algoritma Forward Chaining sesuai dengan rule yang telah ditetapkan.

\section{Metode}

\section{a. Sistem Penunjang Keputusan}

Sistem Penunjang Keputusan (SPK) ialah sekumpulan elemen-elemen dimana tiap elemen saling berhubungan satu sama lainnya untuk memproses sebuah inputan dan penilaian yang menghasilkan sebuah keluaran berupa informasi yang digunakan untuk membuat keputusan[9], [10], SPK memiliki fungsinya membantu dalam pengambilan keputusan bukan sistem yang mutlak untuk menentukan sebuah keputusan baik di dalam keadaan tersturkur atau semi terstruktur[10]. Terdapat beberapa komponen yang dimiliki oleh DSS. Antara lain: Subsistem Manajemen Data, Subsistem Manajemen Model, Subsistem Antarmuka Pengguna dan Subsistem Manajemen Berbasis Pengetahuan yang ditunjukkan pada gambar 1

\section{b. Simple Multi Attribute Rating Technique (SMART)}

SMART adalah metode yang digunakan pengambilan keputusan yang secara keseluruhan dapat menghitung beberapa hal yang memiliki sifat kualitatif dan kuantitatif. Cara yang digunakan dalam penilaian metode ini adalah berupa pembobotan, di mana metode ini melihat beberapa parameter yang digunakan untuk penentuan keputusan, dan pada pemberian bobot, dan range nilai yang diberikan berbeda-beda sesuai seberapa penting dari parameternya[11]. Alur perhitungan dari metode ini, sebagai beikut:

1. Menentukan kriteria yang dibutuhkan.

2. Menentukan nilai bobot dari setiap kriteria yang sebelumnya telah ditentukan sesuai nilai prioritas kriteria dengan menggunakan interval 1-100.

3. Menghitung nilai normalisasi dari hasil perbandingan nilai bobot setiap kriteria dengan jumlah nilai bobot kriteria, menggunakan rumus (1).

$$
\begin{aligned}
& \text { Normalisasi }=\mathrm{W}_{\mathrm{j}} / \sum \mathrm{W}_{\mathrm{j}} \\
& \text { Keterangan: } \\
& \mathrm{W}_{\mathrm{j}}=\text { Bobot setiap kriteria } \\
& \sum \mathrm{W}_{\mathrm{j}}=\text { Total bobot setiap kriteria }
\end{aligned}
$$

4. Memberikan nilai untuk setiap kriteria pada setiap alternatif.

5. Menentukan nilai ultiliti dengan mengubah nilai pada setiap kriteria, menjadi nilai kriteria yang lebih baku, untuk nilai ultiliti didapatkan dari rumus (2).

$$
\mathrm{u}_{\mathrm{i}}\left(\mathrm{a}_{\mathrm{i}}\right)=100\left(\mathrm{C}_{\text {out }}-\mathrm{C}_{\min } / \mathrm{C}_{\max }-\mathrm{C}_{\min }\right) \%
$$

Keterangan:

$\mathrm{u}_{\mathrm{i}}\left(\mathrm{a}_{\mathrm{i}}\right)=$ Nilai ultiliti kriteria ke-1 untuk kriteria ke-i

$\mathrm{C}_{\mathrm{ou}}^{\mathrm{t}}=$ Nilai kriteria ke- $\mathrm{i}$

$\mathrm{C}_{\min }^{\text {ou }}=$ Nilai kriteria minimal

$\mathrm{C}_{\max }=$ Nilai kriteria maksimal

6. Menentukan nilai akhir dari metode ini yaitu dengan cara mengalikan nilai ultiliti yang didapatkan dengan nilai bobot yang telah dinormalisasikan, kemudian hasil perkalian tersebut dijumlahkan. Rumus (3) digunakan untuk mencari nilai akhir.

$u\left(a_{i}\right)=\sum_{j=i}^{m} W j \cdot u_{i} \cdot\left(a_{i}\right)$

Keterangan :

$\mathrm{u}\left(\mathrm{a}_{\mathrm{i}}\right)=$ Nilai total alternatif

$\mathrm{W}_{.}=$Hasil dari normalisasi bobot kriteria

$\mathrm{u}_{\mathrm{i}}\left(\mathrm{a}_{\mathrm{i}}\right)=$ hasil dari penetuan nilai ultiliti[12]

Diagram alur perhitungan menggunakan algortima SMART ditunjukkan pada gambar 2. 


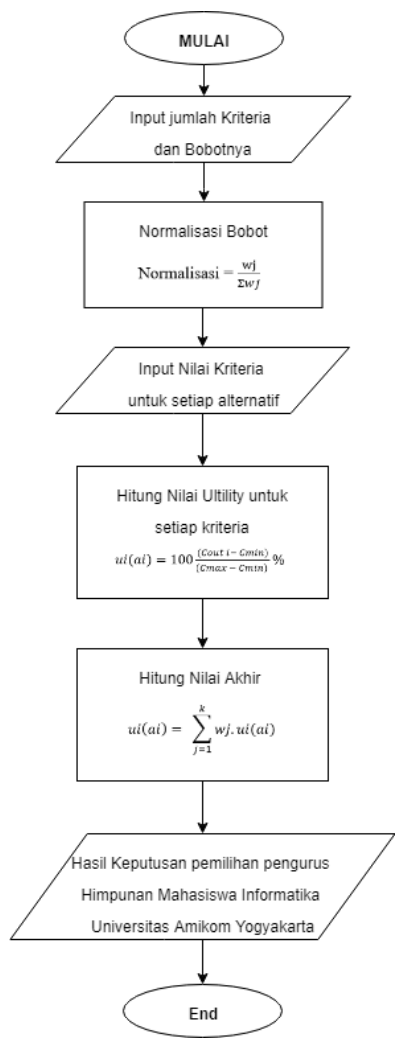

Gambar 2. Proses SMART (simple multi attribute rating technique)

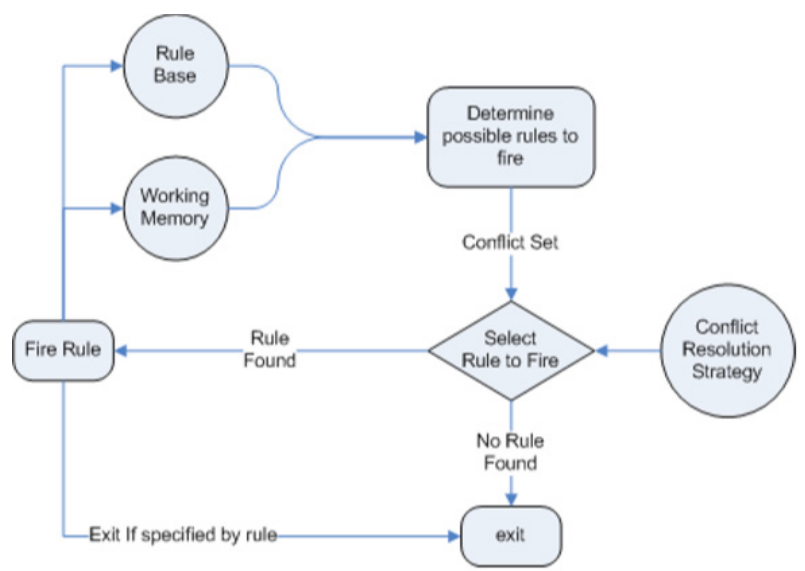

Gambar 3. Proses forward chaining (Sharma, Tiwari, \& Kelkar, 2012)

Tabel 1. Kriteria dan bobot

\begin{tabular}{clcc}
\hline $\begin{array}{c}\text { Id_ } \\
\text { Kriteria }\end{array}$ & Kriteria & $\begin{array}{c}\text { Bobot } \\
\mathbf{( \% )}\end{array}$ & Normalisasi \\
\hline K001 & Kepedulian & 20 & 0.2 \\
K002 & Kritis & 15 & 0.15 \\
K003 & Profesional & 20 & 0.2 \\
K004 & Loyalitas & 25 & 0.25 \\
K005 & Mental & 20 & 0.2 \\
\hline
\end{tabular}

\begin{tabular}{cccccc}
\hline Nama & K001 & K002 & K003 & K004 & K005 \\
\hline C1 & 80 & 100 & 100 & 80 & 100 \\
C2 & 100 & 100 & 100 & 100 & 80 \\
C3 & 80 & 80 & 100 & 80 & 80 \\
C4 & 80 & 80 & 100 & 80 & 80 \\
C5 & 100 & 80 & 100 & 100 & 80 \\
C6 & 40 & 40 & 40 & 40 & 40 \\
C7 & 80 & 80 & 80 & 80 & 80 \\
C8 & 100 & 80 & 100 & 80 & 100 \\
C9 & 100 & 80 & 80 & 80 & 80 \\
C10 & 60 & 80 & 60 & 60 & 80 \\
C11 & 60 & 60 & 60 & 60 & 60 \\
C12 & 80 & 80 & 100 & 100 & 80 \\
C13 & 80 & 80 & 80 & 80 & 80 \\
C14 & 100 & 80 & 80 & 80 & 100 \\
C15 & 100 & 100 & 100 & 100 & 80 \\
C16 & 80 & 80 & 100 & 100 & 100 \\
C17 & 100 & 100 & 80 & 80 & 80 \\
C18 & 80 & 80 & 80 & 80 & 80 \\
C19 & 80 & 80 & 80 & 80 & 80 \\
C20 & 100 & 80 & 100 & 100 & 100 \\
C21 & 80 & 80 & 80 & 80 & 80 \\
C22 & 80 & 80 & 80 & 80 & 80 \\
C23 & 80 & 80 & 60 & 80 & 80 \\
C24 & 100 & 100 & 100 & 100 & 80 \\
C25 & 100 & 80 & 80 & 100 & 80 \\
C26 & 80 & 80 & 100 & 80 & 80 \\
C27 & 80 & 80 & 80 & 80 & 80 \\
C28 & 80 & 80 & 80 & 80 & 80 \\
C29 & 80 & 80 & 80 & 80 & 80 \\
C30 & 80 & 80 & 80 & 80 & 80 \\
C31 & 80 & 80 & 80 & 80 & 80 \\
C32 & 80 & 80 & 100 & 100 & 80 \\
\hline & & & & &
\end{tabular}

\section{c. Forward Chaining}

Forward chaining adalah suatu metode yang sering digunakan untuk sistem pakar (expert system) diagnosis suatu penyakit, di mana metode ini adalah satu metode yang membuktikan hasil diagnosis dari proses-proses pencarian fakta-fakta yang diinputkan yang ditelusuri secara runtut dari satu fakta ke fakta yang lainnya sampai hasilnya didapatkan secara cepat dan tepat sesuai faktafakta yang ada[7], [13]. Metode ini pun sering disebut juga dengan metode runtut maju karena metode ini melacak dengan dimulai dari depan dimulai dari fakta-fakta yang ada dengan penggabungan rule-rule untuk menghasilkan suatu kesimplan atau hasil diagnosisnya, metode ini diawali dengan proses input beberapa fakta, yang kemudian dari beberapa fakta yang diinputkan tersebut akan dikenai beberapa aturan, dan kemudian dari aturan-aturan yang diberikan menghasilkan suatu kesimpulan atau hasil. Metode ini juga memulai pencarian atau penalaran faktafakta yang ada dari sebelah kiri (IF THEN)[14]. Di mana 
mesin pencari menggunakan metode ini dengan mencari aturan-aturan inferensi sampai bisa menemukan dari salah satu hipotesis (klausa IF-THEN) yang benar, kemudian setelah aturan ditemukan maka mesin melanjutkan untuk proses pengambilan keputusan untuk mendapatkan sebuah kesimpulan (THEN), serta menghasilkan tambahan informasi baru dari data yang disediakan. Mesin akan terus mengulang sampai tujuan ditemukan[15] yang ditunjukkan pada gambar 3 .

\section{d. Pengumpulan Data}

Studi kasus dari penelitian ini yaitu penyeleksian dari kader untuk menjadi calon pengurus Himpunan Mahasiswa Informatika Universitas Amikom Yogyakarta.

Data yang digunakan pada penelitian ini dikumpulkan secara langsung dari sumbernya (data primer) yaitu kriteria-kriteria yang diperlukan dan penentuan nilai bobot dari setiap kriteria yang digunakan dalam penilaian. Penentuan jumlah kriteria, kriteria, nilai bobot dari masing-masing kriteria, bagian-bagian dari organisasinya, pernyataan-pernyataan yang akan dipakai ditentukan oleh pihak organisasi itu sendiri.

\section{e. Perancangan Sistem}

Rancangan dari sistem yang dibuat akan berbasis website, diagram konteks, dan diagram alir data akan digunakan untuk membantu dalam perancangan sistem.

\section{Hasil}

\section{a. Implementasi algoritma Simple Multi Attribute Rating Technique}

Terdapat 5 kriteria beserta nilai bobot untuk setiap kriteria yang dihasilkan. Data dari kriteria, nilai bobot serta perhitungan normalisasi terdapat pada tabel 1. Setiap kriteria yang telah dilakukan input nilai kriteria untuk 31 calon alternatif ditunjukkan pada tabel 2. Perhitungan nilai utility dilakukan untuk masing-masing calon alternatif, yang ditunjukkan pada tabel 3. Setelah perhitungan nilai utility, dilakukan perhitungan akhir untuk menentukan beberapa alternatif pengurus organisasi. Tabel hasil perhitungan ditunjukan pada tabel 4. Range nilai untuk rekomendasi keputusan dari organisasi tersebut yang ditunjukan pada tabel 5. Data hasil keputusan pada tabel 4 pihak organisasi merekomendasikan 25 orang nilai tertinggi yang akan diproses dengan metode forward chaining untuk merekomendasikan jabatan masingmasing sesuai dengan pernyataan yang mereka pilih dan datanya yang ditunjukan pada tabel 6 .

\section{b. Implementasi algoritma Forward Chaining}

Fakta-fakta dihimpun dari sejumlah pernyataan untuk implementasi forward chaining terdapat pada tabel 7.

\section{c. Mesin Interferensi}

Analisis data yang dilakukan adalah pengklasifikasian beberapa pernyataan, kemudian digolongkan berdasarkan jenis divisi tertentu yang ditunjukkan pada tabel 8 .
Tabel 3. Nilai utility

\begin{tabular}{cccccc}
\hline Nama & K001 & K002 & K003 & K004 & K005 \\
\hline C1 & 0.75 & 1 & 1 & 0.75 & 1 \\
C2 & 1 & 1 & 1 & 1 & 0.75 \\
C3 & 0.75 & 0.75 & 1 & 0.75 & 0.75 \\
C4 & 0.75 & 0.75 & 1 & 0.75 & 0.75 \\
C5 & 1 & 0.75 & 1 & 1 & 0.75 \\
C6 & 0.25 & 0.25 & 0.25 & 0.25 & 0.25 \\
C7 & 0.75 & 0.75 & 0.75 & 0.75 & 0.75 \\
C8 & 1 & 0.75 & 1 & 0.75 & 1 \\
C9 & 1 & 0.75 & 0.75 & 0.75 & 0.75 \\
C10 & 0.5 & 0.75 & 0.5 & 0.5 & 0.75 \\
C11 & 0.5 & 0.5 & 0.5 & 0.5 & 0.5 \\
C12 & 0.75 & 0.75 & 1 & 1 & 0.75 \\
C13 & 0.75 & 0.75 & 0.75 & 0.75 & 0.75 \\
C14 & 1 & 0.75 & 0.75 & 0.75 & 1 \\
C15 & 1 & 1 & 1 & 1 & 0.75 \\
C16 & 0.75 & 0.75 & 1 & 1 & 1 \\
C17 & 1 & 1 & 0.75 & 0.75 & 0.75 \\
C18 & 0.75 & 0.75 & 0.75 & 0.75 & 0.75 \\
C19 & 0.75 & 0.75 & 0.75 & 0.75 & 0.75 \\
C20 & 1 & 0.75 & 1 & 1 & 1 \\
C21 & 0.75 & 0.75 & 0.75 & 0.75 & 0.75 \\
C22 & 0.75 & 0.75 & 0.75 & 0.75 & 0.75 \\
C23 & 0.75 & 0.75 & 0.5 & 0.75 & 0.75 \\
C24 & 1 & 1 & 1 & 1 & 0.75 \\
C25 & 1 & 0.75 & 0.75 & 1 & 0.75 \\
C26 & 0.75 & 0.75 & 1 & 0.75 & 0.75 \\
C27 & 0.75 & 0.75 & 0.75 & 0.75 & 0.75 \\
C28 & 0.75 & 0.75 & 0.75 & 0.75 & 0.75 \\
C29 & 0.75 & 0.75 & 0.75 & 0.75 & 0.75 \\
C30 & 0.75 & 0.75 & 0.75 & 0.75 & 0.75 \\
C31 & 0.75 & 0.75 & 0.75 & 0.75 & 0.75 \\
\hline & 0.75 & 0.75 & 1 & 1 & 0.75 \\
\hline
\end{tabular}


Tabel 4. Hasil keputusan

\begin{tabular}{cccccccc}
\hline Nama & K001 & K002 & K003 & K004 & K005 & Total & Hasil Keputusan \\
\hline C20 & 0.2 & 0.11 & 0.2 & 0.25 & 0.2 & 0.96 & Sangat Layak \\
C2 & 0.2 & 0.15 & 0.2 & 0.25 & 0.15 & 0.95 & Sangat Layak \\
C15 & 0.2 & 0.15 & 0.2 & 0.25 & 0.15 & 0.95 & Sangat Layak \\
C24 & 0.2 & 0.15 & 0.2 & 0.25 & 0.15 & 0.95 & Sangat Layak \\
C5 & 0.2 & 0.11 & 0.2 & 0.25 & 0.15 & 0.91 & Sangat Layak \\
C16 & 0.15 & 0.11 & 0.2 & 0.25 & 0.2 & 0.91 & Sangat Layak \\
C8 & 0.2 & 0.11 & 0.2 & 0.19 & 0.2 & 0.9 & Sangat Layak \\
C1 & 0.15 & 0.15 & 0.2 & 0.19 & 0.2 & 0.89 & Sangat Layak \\
C12 & 0.15 & 0.11 & 0.2 & 0.25 & 0.15 & 0.86 & Sangat Layak \\
C25 & 0.2 & 0.11 & 0.15 & 0.25 & 0.15 & 0.86 & Sangat Layak \\
C32 & 0.15 & 0.11 & 0.2 & 0.25 & 0.15 & 0.86 & Sangat Layak \\
C14 & 0.2 & 0.11 & 0.15 & 0.19 & 0.2 & 0.85 & Sangat Layak \\
C17 & 0.2 & 0.15 & 0.15 & 0.19 & 0.15 & 0.84 & Sangat Layak \\
C3 & 0.15 & 0.11 & 0.2 & 0.19 & 0.15 & 0.8 & Sangat Layak \\
C4 & 0.15 & 0.11 & 0.2 & 0.19 & 0.15 & 0.8 & Sangat Layak \\
C9 & 0.2 & 0.11 & 0.15 & 0.19 & 0.15 & 0.8 & Sangat Layak \\
C26 & 0.15 & 0.11 & 0.2 & 0.19 & 0.15 & 0.8 & Sangat Layak \\
C7 & 0.15 & 0.11 & 0.15 & 0.19 & 0.15 & 0.75 & Layak \\
C13 & 0.15 & 0.11 & 0.15 & 0.19 & 0.15 & 0.75 & Layak \\
C18 & 0.15 & 0.11 & 0.15 & 0.19 & 0.15 & 0.75 & Layak \\
C19 & 0.15 & 0.11 & 0.15 & 0.19 & 0.15 & 0.75 & Layak \\
C21 & 0.15 & 0.11 & 0.15 & 0.19 & 0.15 & 0.75 & Layak \\
C22 & 0.15 & 0.11 & 0.15 & 0.19 & 0.15 & 0.75 & Layak \\
C27 & 0.15 & 0.11 & 0.15 & 0.19 & 0.15 & 0.75 & Layak \\
C28 & 0.15 & 0.11 & 0.15 & 0.19 & 0.15 & 0.75 & Layak \\
C29 & 0.15 & 0.11 & 0.15 & 0.19 & 0.15 & 0.75 & Layak \\
C30 & 0.15 & 0.11 & 0.15 & 0.19 & 0.15 & 0.75 & Layak \\
C31 & 0.15 & 0.11 & 0.15 & 0.19 & 0.15 & 0.75 & Layak \\
C23 & 0.15 & 0.11 & 0.1 & 0.19 & 0.15 & 0.7 & Layak \\
C10 & 0.1 & 0.11 & 0.1 & 0.13 & 0.15 & 0.59 & Layak \\
C11 & 0.1 & 0.08 & 0.1 & 0.13 & 0.1 & 0.5 & Dipertimbangkan \\
\hline & 0.05 & 0.04 & 0.05 & 0.06 & 0.05 & 0.25 & Tidak Layak \\
\hline
\end{tabular}

Tabel 5. Range nilai keputusan

\begin{tabular}{lc}
\hline \multicolumn{1}{c}{ Predikat } & Keterangan \\
\hline Sangat layak & $>=0.8$ \\
Layak & $>=0.55$ \\
Dipertimbangkan & $>=0.35$ \\
Tidak Layak & $>=0$ \\
\hline
\end{tabular}

Tabel 6. Data input untuk proses Forward Chaining 


\begin{tabular}{cccccccc}
\hline Nama & K001 & K002 & K003 & K004 & K005 & Total & $\begin{array}{c}\text { Hasil } \\
\text { Keputusan }\end{array}$ \\
\hline C20 & 0.2 & 0.11 & 0.2 & 0.25 & 0.2 & 0.96 & Sangat Layak \\
C2 & 0.2 & 0.15 & 0.2 & 0.25 & 0.15 & 0.95 & Sangat Layak \\
C15 & 0.2 & 0.15 & 0.2 & 0.25 & 0.15 & 0.95 & Sangat Layak \\
C24 & 0.2 & 0.15 & 0.2 & 0.25 & 0.15 & 0.95 & Sangat Layak \\
C5 & 0.2 & 0.11 & 0.2 & 0.25 & 0.15 & 0.91 & Sangat Layak \\
C16 & 0.15 & 0.11 & 0.2 & 0.25 & 0.2 & 0.91 & Sangat Layak \\
C8 & 0.2 & 0.11 & 0.2 & 0.19 & 0.2 & 0.9 & Sangat Layak \\
C1 & 0.15 & 0.15 & 0.2 & 0.19 & 0.2 & 0.89 & Sangat Layak \\
C12 & 0.15 & 0.11 & 0.2 & 0.25 & 0.15 & 0.86 & Sangat Layak \\
C25 & 0.2 & 0.11 & 0.15 & 0.25 & 0.15 & 0.86 & Sangat Layak \\
C32 & 0.15 & 0.11 & 0.2 & 0.25 & 0.15 & 0.86 & Sangat Layak \\
C14 & 0.2 & 0.11 & 0.15 & 0.19 & 0.2 & 0.85 & Sangat Layak \\
C17 & 0.2 & 0.15 & 0.15 & 0.19 & 0.15 & 0.84 & Sangat Layak \\
C3 & 0.15 & 0.11 & 0.2 & 0.19 & 0.15 & 0.8 & Sangat Layak \\
C4 & 0.15 & 0.11 & 0.2 & 0.19 & 0.15 & 0.8 & Sangat Layak \\
C9 & 0.2 & 0.11 & 0.15 & 0.19 & 0.15 & 0.8 & Sangat Layak \\
C26 & 0.15 & 0.11 & 0.2 & 0.19 & 0.15 & 0.8 & Sangat Layak \\
C7 & 0.15 & 0.11 & 0.15 & 0.19 & 0.15 & 0.75 & Layak \\
C13 & 0.15 & 0.11 & 0.15 & 0.19 & 0.15 & 0.75 & Layak \\
C18 & 0.15 & 0.11 & 0.15 & 0.19 & 0.15 & 0.75 & Layak \\
C19 & 0.15 & 0.11 & 0.15 & 0.19 & 0.15 & 0.75 & Layak \\
C21 & 0.15 & 0.11 & 0.15 & 0.19 & 0.15 & 0.75 & Layak \\
C22 & 0.15 & 0.11 & 0.15 & 0.19 & 0.15 & 0.75 & Layak \\
C27 & 0.15 & 0.11 & 0.15 & 0.19 & 0.15 & 0.75 & Layak \\
C28 & 0.15 & 0.11 & 0.15 & 0.19 & 0.15 & 0.75 & Layak \\
\hline & & & & & & &
\end{tabular}


Tabel 7. Tabel pernyataan

\begin{tabular}{|c|c|}
\hline ID & Pernyataan \\
\hline P001 & Biasa mengelola dan mengerti semua administrasi yang berlaku secara baik. \\
\hline P002 & Mengerti dan pintar dalam mengelola di bidang surat menyurat \\
\hline P003 & Dapat mengatur agenda atau jadwal dari setiap kegiatan yang telah dibuat \\
\hline P004 & Memiliki kemampuan koordinasi yang baik dalam menentukan dan membuat kebijakan \\
\hline P005 & Bisa bekerja dalam tim dan memiliki kemampuan koordinasi yang baik \\
\hline P006 & Bisa bekerja dalam tekanan \\
\hline P007 & Baik dalam pengelolaan administrasi keuangan \\
\hline P008 & Memiliki kemampuan mengatur pola keuangan yang baik \\
\hline P009 & Trasparan terhadap semua bentuk transaksi untuk semua transaksi yang dilakukan \\
\hline P010 & Amanah untuk mengembang pengatur keuangan \\
\hline P011 & Bisa mengambil keputusan yang cepat dan tepat terkait keuangan yang akan dipakai. \\
\hline P012 & Mengikuti perkembangan teknologi setiap saat \\
\hline P013 & Tertarik dan mengikuti perkembangan di dunia penelitian \\
\hline P014 & Tertarik pada hal yang baru untuk menguliknya \\
\hline P015 & Bisa berfikir yang out of the box \\
\hline P016 & Suka dalam membuat penelitian terhadap apa yang ada di sekitar \\
\hline P017 & Suka dalam berbagi ilmu pengetahuan kepada orang lain \\
\hline P018 & Suka berhubungan dengan orang baru \\
\hline P019 & Bisa menjalin relasi yang baik dengan partner atau orang lain \\
\hline P020 & Bisa menjadi penghubung yang baik organisasi dengan personal dan institusi baik didalam atau diluar kampus. \\
\hline P021 & Aktif dalam penyerbaran informasi yang informatif \\
\hline P022 & Aktif dalam media sosial \\
\hline P023 & Bisa peka terhadap fenomena yang ada di sekitar dalam bentuk apapun \\
\hline P024 & Bisa berfikir kritis atas fenomena yang terjadi \\
\hline P025 & Bisa mengawal isu-isu yang ada yang ada di lingkungan sekitar sampai mendapatkan kejelasan \\
\hline P026 & Bisa melihat masalah dan fenomena yang terjadi dari segala aspek dan sudut \\
\hline P027 & Bisa mendengarkan keluh kesah dari sekitar kita terkait apa yang terjadi \\
\hline P028 & Bisa memperjuangankan hak-hak yang harusnya didapatkan \\
\hline P029 & Mempunyai manajemen manusia yang sangat baik \\
\hline P030 & Mengerti dengan baik terkait keadaan yang ada pada internal organisasi \\
\hline P031 & Bisa menjadi wadah curhatan semua orang yang berada pada internal organisasi \\
\hline P032 & Bisa memahami keadaan semua staff diinternal organisasi dengan \\
\hline P033 & Memiliki pendakatan yang baik kepada setiap staff yang ada pada internal \\
\hline
\end{tabular}

Tabel 8. Aturan pernyataan

\begin{tabular}{cll}
\hline ID & \multicolumn{1}{c}{ Divisi } & \multicolumn{1}{c}{ ID_Aturan } \\
\hline D001 & Sekretaris & P001, P002, P003, P004, P005, P006 \\
D002 & Bendahara & P007, P008, P009, P010, P011, P005, P006 \\
D003 & Humas & P018, P019, P020, P021, P022, P005, P006 \\
D004 & Penelitian Dan Pengembangan & P012, P013, P014, P015, P016, P017, P005, P006 \\
D005 & Keorganisasian & P029, P030, P031, P032, P033, P005, P006 \\
D006 & Aspirasi & P023, P024, P025, P026, P027, P028, P005, P006 \\
\hline
\end{tabular}


Tabel 9. Hasil pencarian

\begin{tabular}{|c|c|c|c|c|c|c|c|}
\hline Nama & P1 & $\mathbf{P} 2$ & P3 & P4 & P5 & Kode Posisi & Nama Posisi \\
\hline $\mathrm{C} 20$ & P001 & P002 & P003 & P004 & P005 & D001 & Sekertaris \\
\hline $\mathrm{C} 2$ & P007 & P008 & P009 & P010 & P011 & D002 & Bendahara \\
\hline C15 & P007 & P008 & P009 & P010 & P011 & D002 & Bendahara \\
\hline $\mathrm{C} 24$ & P001 & P002 & P003 & P004 & P005 & D001 & Sekertaris \\
\hline C5 & P001 & P002 & P003 & P004 & P005 & D001 & Sekertaris \\
\hline C16 & P018 & P019 & P020 & P021 & P022 & D003 & Humas \\
\hline $\mathrm{C} 8$ & P023 & P024 & P025 & P026 & P027 & D005 & Keorganisasian \\
\hline C1 & P012 & P013 & P014 & P015 & P016 & D004 & Litbang \\
\hline C12 & P023 & P024 & P025 & P026 & P027 & D005 & Keorganisasian \\
\hline $\mathrm{C} 25$ & P012 & P013 & P014 & P015 & P016 & D004 & Litbang \\
\hline C32 & P023 & P024 & P025 & P026 & P027 & D005 & Keorganisasian \\
\hline C14 & P018 & P019 & P020 & P021 & P022 & D003 & Humas \\
\hline C17 & P012 & P013 & P014 & P015 & P016 & D004 & Litbang \\
\hline C3 & P029 & P030 & P031 & P032 & P033 & D006 & Aspirasi \\
\hline $\mathrm{C} 4$ & P029 & P030 & P031 & P032 & P033 & D006 & Aspirasi \\
\hline C9 & P005 & P006 & P017 & P028 & P001 & D004/D006 & Litbang/ Aspirasi \\
\hline $\mathrm{C} 26$ & P023 & P024 & P025 & P026 & P027 & D005 & Keorganisasian \\
\hline $\mathrm{C} 7$ & P001 & P002 & P007 & P008 & P006 & D001/D002 & Sekertaris/ Bendahara \\
\hline C13 & P023 & P024 & P025 & P026 & P027 & D005 & Keorganisasian \\
\hline C18 & P012 & P013 & P014 & P015 & P016 & D004 & Litbang \\
\hline C19 & P018 & P019 & P020 & P021 & P022 & D003 & Humas \\
\hline C21 & P012 & P013 & P014 & P015 & P016 & D004 & Litbang \\
\hline $\mathrm{C} 22$ & P018 & P019 & P020 & P021 & P022 & D003 & Humas \\
\hline $\mathrm{C} 27$ & P029 & P030 & P031 & P032 & P033 & D006 & Aspirasi \\
\hline $\mathrm{C} 28$ & P029 & P030 & P031 & P032 & P033 & D006 & Aspirasi \\
\hline
\end{tabular}

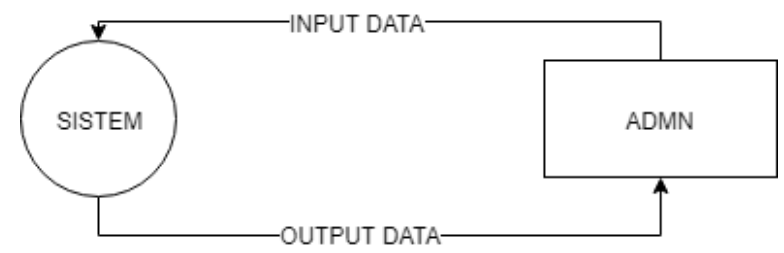

Gambar 4. Diagram konteks

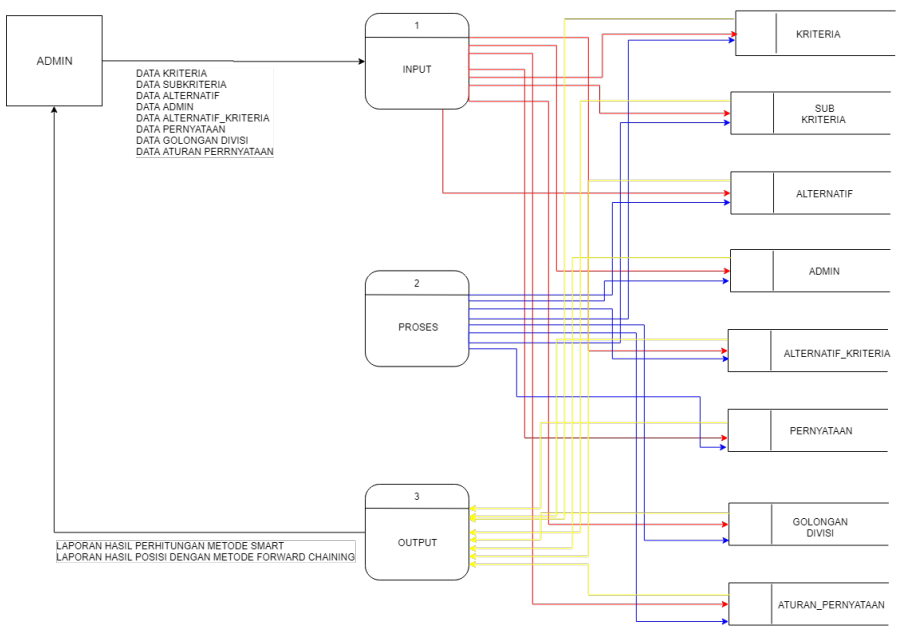

Gambar 5. Diagram alir data level 1 


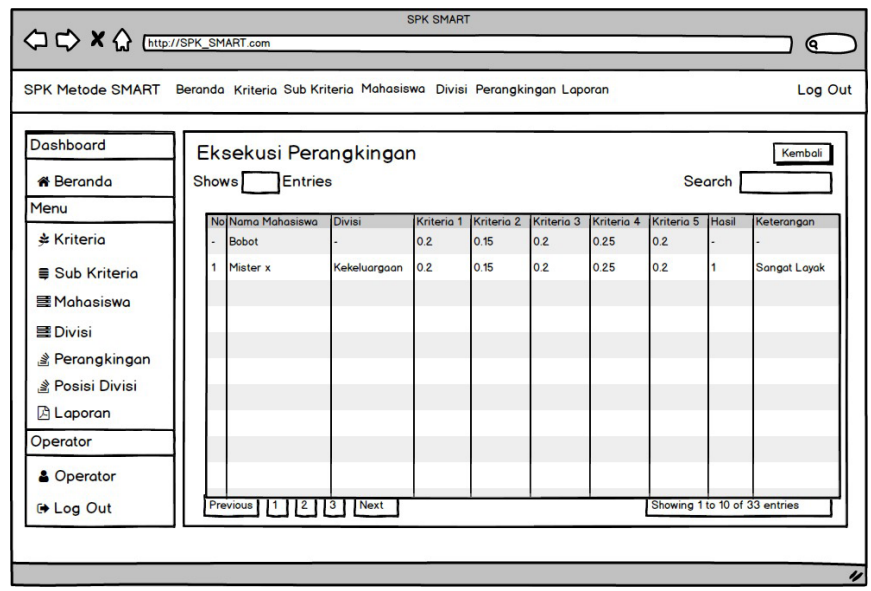

Gambar 6. Interface Hasil Perangkingan/Peringkat

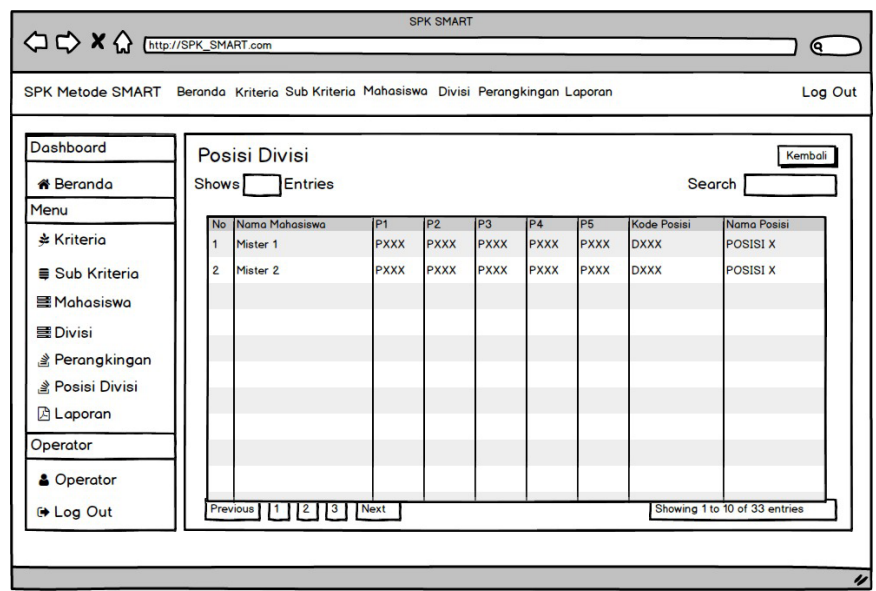

Gambar 7. Interface hasil metode forward chaining

Setiap divisi memiliki beberapa aturan yang selanjutnya menjadi sebuah kaidah berbasis aturan, kemudian dilakukan proses pengecekan apakah kaidahkaidah tersebut sesuai atau tidak terhadap fakta-fakta dari user, jika sesuai maka fakta tersebut tersimpan dalam file berbasis pengetahuan sebagai pertimbangan untuk mendapatkan hasil keputusan, jika tidak sesuai maka user akan memberikan fakta-fakta yang lain. Proses pelacakan untuk mencari fakta yang sesuai dengan aturan IF-THEN.

Hasil perhitungan dari metode Simple Multi Attribute Rating Technique (SMART) sebanyak 25 orang dengan nilai tertinggi, kemudian setelah itu dilanjutkan dengan proses pengalokasian jabatan dengan menggunakan forward chaining, yang diawali dengan proses pengisian pernyataan, hasilnya ditunjukkan pada tabel 9.

\section{d. Diagram Konteks}

Diagram konteks sistem pendukung keputusan dengan kombinasi metode simple multi attribute rating technique dan forward chaining, yang ditunjukan pada gambar 4.

\section{e. Diagram Alir Data Level 1}

Diagram alir data level 1 sistem pendukung keputusan dengan kombinasi metode simple multi attribute rating technique dan forward chaining, ditunjukan pada gambar 5.

\section{f. Desain User Interface Sistem}

Proses pertama yang dilakukan adalah implementasi metode SMART untuk menentukan sejumlah orang dengan nilai tertinggi, userinterface sistem akan menampilkan calon kandidat pengurus organisasi. Rancangan desain User interface hasil penilaian peringkat ditunjukkan pada gambar 6.

Hasil penilaian dengan nilai tertinggi dilanjutkan dengan proses metode forward chaining untuk penentuan posisi divisi atau jabatan sesuai dengan pernyataan yang telah diisi dengan desain user interface ditunjukkan pada gambar 7 .

\section{Kesimpulan}

Penelitian ini telah menghasilkan 25 orang kandidat pengurus organisasi dengan nilai terbaik dan sekaligus merekomendasikan posisi jabatan sekretaris sebanyak 3 orang, 2 orang bendahara, 4 orang jabatan aspirasi, bagian humas 4 orang, Litbang berjumlah 5 orang, keorganisasian sebanyak 5 orang, 1 orang jabatan Litbang atau jabatan aspirasi serta jabatan bendahara atau sekretaris sebanyak 1 orang.

Penggunaan kombinasi 2 (dua) metode yang diterapkan dengan metode Simple Multi Attribute Rating Technique (SMART) dan Forward Chaining 
telah menghasilkan output yang tidak hanya mencari dan menghasilkan sejumlah calon anggota organisasi akan tetapi calon tersebut direkomendasikan ke posisi jabatan masing-masing, sehingga dapat memberikan hasil yang lebih spesifik dan posisi yang tepat serta memudahkan dalam pengambilan sebuah keputusan, sehingga bisa menutupi kelemahan algoritma Simple Multi Attribute Rating Technique (SMART).

Penggunaan dari kedua metode ini masih memiliki kelemahan yaitu belum dapat menyajikan persentase perbandingan yang lebih besar jika proses yang dihasilkan terdapat 2 klasifikasi atau lebih.

\section{Daftar Pustaka}

[1] S. Aswati, N. Mulyani, Y. Siagian, and A. Z. Syah, "Peranan Sistem Informasi Dalam Perguruan Tinggi," J. Teknol. dan Sist. Inf., vol. 1, no. 2, pp. 79-86, 2015.

[2] R. Sukmawati and E. K. Dewi, "Implementasi Metode SMART untuk Mengidentifikasi Perkembangan Anak dalam Mengikuti Ekstra," J. Nusantara of Engineering, vol. 3, no. 1, pp. 59-64, maret 2016.

[3] A. S. Honggowibowo, "Sistem Pendukung Keputusan Penerimaan Calon Teknologi Adisutjipto Menggunakan Simple Multi Attribute Rating Technique," J. angkasa, vol. VII, no. 2, pp. 31-38, 2015.

[4] H. R. Hatta, B. Gunawan, and D. M. Khairina, "Pemilihan Pemain Terbaik Futsal Dengan Metode Simple Multi Attribute Rating Tecnique Studi Kasus : Turnamen Futsal Di Samarinda," Jurnal Informatika, vol. 11, pp. 1-8, 2017.

[5] R. R. Fanny, N. A. Hasibuan, and E. Buulolo, "Perancangan Sistem Pakar Diagnosa Penyakit Asidosis Tubulus Renalis Menggunakan Metode Certainty Factor Dengan Penulusuran Forward Chaining," Media Inform. Budidarma, vol. 1, no. 1, pp. 13-16, januari 2017.

[6] R. Tri, T. Saptawati, and H. Pramono, "Kombinasi Metode Forward Chaining dan Analytic Hierarchy Process Untuk Pengelolaan Bahan Praktikum Laboratorium Biologi," J. EECCIS, vol. 10, no. 2, pp. 51-58, 2016.
[7] B. F. Yanto, I. Werdiningsih, and E. Purwanti, "Aplikasi Sistem Pakar Diagnosa Penyakit Pada Anak Bawah Lima Tahun Menggunakan Metode Forward Chaining," J. Inf. Syst. Eng. Bus. Intell., vol. 3, no. 1, pp. 61-67, 2017.

[8] Y. Ek. Nugraha, B. Irawan, and R. E. Saputra, "Pengembangan Sistem Otomatisasi Pengendaluan Nutrisi Pada Hidroponik Menggunakan Sistem Pakar Dengan Metode Forward Chaining," e-Proceeding Eng., vol. 4, no. 2, pp. 2199-2206, 2017.

[9] S. Mesdina, "Perancangan Aplikasi Penilaian Hasil Kinerja Dosen Terbaik Dengan Metode Simple Multi Attribute Rating Technique (Studi Kasus : Akper Yayasan Binalita Sudama Medan," J.Hasil Riset, vol. IX, pp. 129-133, 2015.

[10] A. Wanto and E. Kurniawan, "Seleksi Penerimaan Asisten Laboratorium Menggunakan Algoritma AHP Pada AMIK-STIKOM Tunas Bangsa Pematangsiantar," J. Inform. dan Komput., vol. 3, no. 1, pp. 11-18, 2018.

[11] E. Yulianti, "Jurnal Momentum ISSN : 1693-752X Sistem Pendukung Keputusan Pemilihan Mobil Dengan Metoda Simple Multy Attribute Rating ( SMART ), Jurnal Momentum ISSN : 1693-752X," J. Momentum, vol. 17, no. 1, pp. 55-59, 2015.

[12] D. Novianti, I. F. Astuti, and D. M. Khairina, "Sistem Pendukung Keputusan Berbasis Web Untuk Pemilihan Café Menggunakan Metode Smart ( Simple Multi-Attribute Rating Technique ) ( Studi Kasus : Kota Samarinda )," Semin. Sains dan Teknol. FMIPA Unmul, pp. 1-5, 2016.

[13] E. D. Widianto, Y. W. Zaituun, and I. P. Windasari, "Aplikasi Sistem Pakar Pendeteksi Penyakit Tuberkulosis Berbasis Android," J. Ilmiah Ilmu Komputer dan Informatika : khazanah Informatika, vol. 4, no. 1, pp. 47-54, 2018.

[14] N. R. D. P. A and Y. P. Pamungkas, "Deteksi dini perilaku penyimpangan seksual menggunakan metode forward chaining berbasis web," J.Informatika, Vol. 3, pp. 52-58, 2018

[15] I. Akil, P. Studi, M. Administrasi, and J. Timur, "ANALISA EFEKTIFITAS METODE FORWARD CHAINING DAN," J. Pilar Nusa Mandiri, vol. 13, no. 1, pp. 35-42, 2017. 